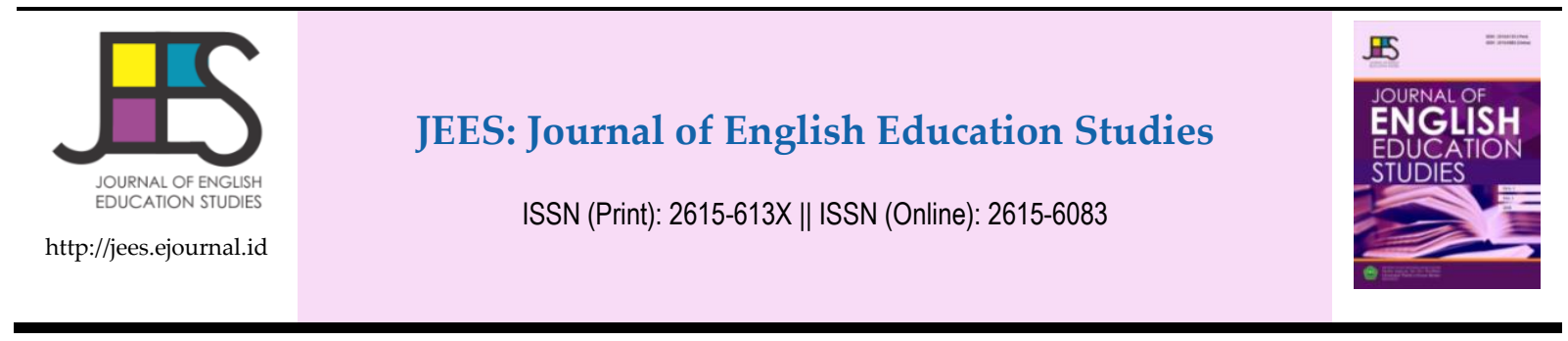

\title{
The Effect of Using Crossword Puzzle Towards Students' Vocabulary Mastery in the Eleventh Grade Students of SMA Muhammadiyah 2 Bandar Lampung in Academic Year 2017-2018
}

\author{
Melasari ${ }^{1}$, Krisna Ismawati ${ }^{2}$, Deri Sis Nanda ${ }^{3}$
}

${ }^{1}$ English Education Study Program, Universitas Bandar Lampung, ${ }^{2}$ English Education Study Program, Universitas Bandar Lampung, ${ }^{3}$ English Education Study Program, Universitas Bandar Lampung

\section{ARTICLE INFO}

Keywords:

Crossword Puzzle,

Vocabulary, Mastery

\begin{abstract}
This research describes the use of Crossword Puzzle to improve students' vocabulary mastery. Moreover, it was to find out whether Crossword Puzzle is effective to improve students' vocabulary mastery at the second grade students of SMA Muhammadiyah 2 Bandar Lampung. This research used experimental design in which the samples of the research were assessed both before and after an experimental treatment. The subject of the research consisted of 68 students, they were divided into experimental and control group. The instruments used for collecting the data were test which was consisted of pretest and posttest. The data analysis of this research was attempted by using independent sample T-test which was calculated through computing with statistical package for Social Science (SPSS) version 20.The result indicated that the students' mean score of experimental and control group in post-test were significantly different. It showed that $\mathrm{t}$-count was higher than $\mathrm{t}$-table $(4.454>1.9966)$ and the sig. 2-tailed value was lower than sig. Level $(0.000>0.05)$. Therefore the null hypothesis $(\mathrm{Ho})$ was rejected and the alternative hypothesis $(\mathrm{Ha})$ was accepted. It meant that there was effective impact of using crossword puzzle towards students' vocabulary mastery. Decision based on facts, using crossword puzzle as a technique was effective to improve students' vocabulary. Therefore, it was suggested the use of crossword puzzle as a technique in teaching English generally and teaching Vocabulary specifically
\end{abstract}

This is an open access article distributed under the terms of the Creative Commons Attribution 4.0 International License, which permits unrestricted use, distribution, and reproduction in any medium, provided the original work is properly cited. @ 2019 Melasari, Krisna Ismawati, Deri Sis Nanda

\section{INTRODUCTION}

Vocabulary is one of the most important aspects in learning English, Richards and Renandya (2002) said that vocabulary is essential part of language proficiency and provides a lot of the basis of how well learners listen, write and speak in learning English. Mastery of vocabulary will affect a person's ability in using the language either in oral or written form. In listening skills to

${ }^{1}$ Corresponding author's address: English Education Study Program, Universitas Bandar Lampung, Bandar Lampung, Indonesia e-mail: melasari288@gmail.com

${ }^{2}$ Corresponding author's address: English Education Study Program, Universitas Bandar Lampung, Bandar Lampung, Indonesia e-mail: krisnaismawati@gmail.com

${ }^{3}$ Corresponding author's address: English Education Study Program, Universitas Bandar Lampung, Bandar Lampung, Indonesia e-mail: derisisnanda@ubl.ac.id 
be able to understand a person's sayings, a person should know what the words and sentences are being said.

Therefore, they know the meaning of speech and can react either through actions or answers using oral utterances. Which here, they have to use words to do that. In addition, to be able to understand what people are reading, they should be able to understand the meaning that is being conveyed through the written word. As we need in speaking, person should be able to organize words to convey meaning in writing. Sure, they should be able to spell words and write them down. Vocabulary means all words used in English. We should master vocabulary so that we can easily use an English language, whether it is making sentences or conversations. The person whose original language is English like the English or American, they may be able to master all English words, therefore they can speak English naturally. However, we should learn more deeply about English vocabulary.

The venue of EFL vocabulary in the Indonesian curriculum seems to be changed according to the existing curriculum, felt from change the objectives and teaching methods of English in Indonesia. As vocabulary is significantly problematic because in Indonesia the implemented curriculum doesn't emphasize on the vocabulary mastery adequately due to limited hours provided for English subject at the schools in Indonesia, lack of exposure of English learning and lack of reading English. It needs a lot of practices, and it needs to be learned and used every day, Mochamad Subhan Zein (2012). David Wilkins, quoted Thornbury (2002:13) concluded about the importance of learning vocabulary by saying "Without Grammar very little can be conveyed, without vocabulary nothing can be conveyed. "He explained that without (knowing) grammar, very little we can express, but without (knowing) the vocabulary, there is nothing we can express. It is true what is revealed by the Wilkins. Although we have good grammar (grammar) ability, but the ability will be in vain if we do not have enough mastery of vocabulary.

When I did an internship (PPL) in SMA Al-Azhar 3 Bandar Lampung, I taught my students about describing people, to speak about describing people they need to arrange some words, they should understand the meaning and they should be able to spell the word. I asked one by one a student to came forward but they difficult to speak, they don't have enough vocabulary. I found some evidences in a learning process that they were difficult to speak. They were still confused about the meaning of the words. They often asked the words in a learning process. They had difficulties when I asked them to make sentences using English about describing people. Another problem that I found in the class was that they did not feel enthusiastic while doing a learning process. They had difficulties in understanding about what they read and listened. However, the students did wrong interpretation words of meaning in the sentences. Prasetyo, Kurniawati, and Subari (2013) said "English teacher should apply various media to improve students' ability in mastering English skills" therefore, I am interested in teaching students using vocabulary games to improve their enthusiasm in learning English vocabulary and their vocabulary mastery.

(Harmer 2007:289) said that vocabulary can be practiced by make a conversation with classmate everyday or we can improve vocabulary mastery by vocabulary game, such as crossword puzzle. Researchers and collaborators determined to apply crossword puzzles to help students improve their vocabulary mastery. As has been stated by Soeparno (1980:73) Crossword is a type of game that is done by filling in a blank form presented with letters those form words in response of question given. Harry Dhand (2008: 55-56) said about benefits of crossword puzzle included, it makes students have more motivation in learning process, it can easily made by teacher. Thus, using the technique of crossword, researchers and collaborators expect the students to have a fun atmosphere in learning English and helping them improve their vocabulary mastery. 
Crossword puzzle is an overview of Puzzle games according to Rinaldi Munir (2005) (http: //www.cse.ohio.html) is a rectangular game consisting of black-and-white squares and 2 horizontal lines (box collection in the form one row and multiple columns) and decreases (single column and multiple rows). The crossword puzzle is a puzzle in which words that match the number hint can be found and written in the box in the puzzle, Collins (2006). Then, Crossword puzzle is one of interesting way to improve students' vocabulary mastery. By using crossword puzzle students can be easier in learning vocabulary because they will learn by playing puzzle game.

\section{METHODOLOGY}

This research used experimental research for two groups design. The first is experimental group and second is control group. Therefore, in this research, firstly researcher would give a pre-test to know their initial vocabulary mastery before treatment was given. Treatment was given to the students in three meetings. One group was given crossword puzzle for every meeting and another group was without crossword puzzle. The post-test was given after the last treatment to know the effect of crossword puzzle on students' vocabulary mastery.

Variable in this research was divided into two parts. The first variable was dependent variable and the second was independent variable. Dependent variable is something that depends on the independent variables; it is outcomes or result of the effect of independent variables. Dependent variable in this research was students' vocabulary. Independent variable is something that causes effect an outcome. Independent variable in this research was crossword puzzle.

This research would be conducted at SMA Muhammadiyah 2 Bandar Lampung in academic year of 2017/2018. The populations of this research were 136 of 4 classes (II IPA 1, II IPA 2, II IPS 1, II IPS 2), two classes were taken to be the experimental and control class. Students at grade II of SMA Muhammadiyah 2 Bandar Lampung.

Researcher would use two classes, one class was for experimental group and another one was for control group. Each class consists of 34 students. Researcher used cluster random sampling in this research because researcher took the sample in a group. Cluster random sampling is a sampling method in which different groups in a population are used as samples. In choosing which class was experimental and control class, researcher put the name of every class into a glass then shacked it. From this sampling technique the experimental class was class II Grade science I, and the control class was class II Grade Science.

The instrument used in this study is the test. There were pre-test and post-test. The purpose of this test was used to identify students' vocabulary improvement. Pre-test was the first activity of this research. This was done at the first meeting and followed by experimental and control groups. The post-test was used to know the result from both of control group and experimental group.

Data would be collected by providing pretest and posttest in the experimental and control groups. Pretest was given at the first meeting, while posttest was given in the last meeting or after treatment was done. Researcher gave 40 questions about vocabulary adjectives Then researcher would give a score by comparing the student's mastery of the vocabulary. The more they can answer correctly, the more points they get. After getting the raw score, researchers tabulated the test results and calculate the pretest and posttest scores. The pretest and posttest scores were calculated using the Arikunto formula (2010) with a total score of 100.

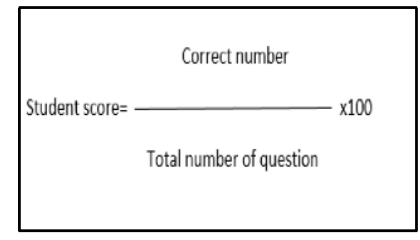


Figure Arikunto's Formula

The figure above indicates that the student's score is the result of the number of correct answers divided by the number of questions multiplied by 100 . For example, when student A can answer 30 questions out of 40 question tested, meaning that the value is 30 divided by 40 multiplied by 100 , the result is 75 therefore, the value of student $A$ is 75.

In the data analysis, researcher would analyze data from pretest and posttest. Data were analyzed to determine whether there is a significant difference between experimental group and control group scores. Data was computed via computation with Statistical Package for Social Sciences (SPSS) version 20. Data were analyzed by using independent $t$-test sample at a significance level of 0.05. Hartono (2008), the results of the tests of the experimental group and control group analyze statically using t-Test for two groups design. The t-Test is applied to know the effect of using crossword puzzle technique between two scores of pre-test and post-test of teaching vocabulary. It means that t-Test will be used to see if there is a significance effect of using crossword puzzle technique on the student's vocabulary mastery.

\section{RESULT AND DISCUSSION}

There are three aspects that are described. The students' achievement in experimental group, the students' achievement in control group and the last is the result of t-Test analysis. The students' achievement in experimental group shows us the students score both before and after the treatments in experimental group. Same as in the students' achievement in experimental group, the students' achievement in control group also shows the students' score before as well as after the treatments in control group. Result of $\mathrm{t}$-test analysis reports the computation of $\mathrm{t}$-test towards the scores of pretest and posttest of experimental and control group.

\section{The Students' Achievement in Experimental Group}

The experimental group was done in Grade II Science I. There are 34 students included; it consists of 11 male students and 23 female students. They were taught by using crossword puzzle to improve their vocabulary. Therefore, in order to know the students' vocabulary mastery before and after treatments, researcher manages pretest and postest. In the pretest, the lowest score is 47.5 and the highest score is 85 . There are 1 student who get the lowest score and 2 students who get highest. In the posttest, the lowest score is 75 and the highest score is 97.5. There are 3 students who get the lowest score and 1 student who gets the highest one. The total score of pretest is 2349.7 and posttest is 2807.5 . Meanwhile, the mean score of pre-test is 69,11 and the mean score of post-test is 82,57 . So, researcher concludes that there is quite improvement of the students' vocabulary after treatments.

\section{The Students' Achievement in Control Group}

The control group was done in II science II class. There are 34 students involve in there, it consists of 8 male students and 27 female students. The treatments of control group were done by using traditional teaching. Therefore, in order to know the students' vocabulary mastery before and after treatments, Researcher manages pretest and posttest.

After obtaining pretest and posttest data, the SPSS program is used to calculate the average value of the experimental and control group, and to test the hypothesis. SPSS is used to reduce errors in calculations and make t-test analysis simpler and more efficient. In using this kind of software researcher just need to put the pretest and posttest values of the experiment group and control into the software, it will be calculated by the software. The data were analyzed by using independent sample t-test analysis. 
This analysis was used to compare experimental and control groups on pretest and posttest vocabulary, and to determine the effect of using crossword puzzles to improve student vocabulary mastery. Then, the results of calculation of $t$-test value consult to $t$-value table. If $t$-value or $t$-count is higher than $t$-table ( $t$-count $>t$-table) and significance value is lower than significance level of 0.05 (sig. 2-tailed value $<0.05$ ), it means there is impact of using crossword puzzle on students' vocabulary mastery.

Firstly, Researcher examines the result of the experimental and control group in pretest. Table 4.1 and 4.2 demonstrate the result of independent sample t-test of the experimental and control group in the pretest. It indicates that there is no any significant difference between experimental and control groups' mean scores in the pretest of vocabulary. Therefore, the alternative hypothesis (Ha) as there is impact of using crossword puzzle on students' vocabulary mastery is rejected. In brief, each group consists of students with similar proficiency level of vocabulary before treatments are given.

Second, researcher goes over the result of the experimental and control group in posttest. The result of this research shows that the students' scores of both experimental and control group are quite low in the pretest. The total scores of experimental group is 2349.7, while the total score of control group is 2176. The mean score of control experimental group is 69.11 while control group is 65. In the pretest, from 40 questions which are tested the students are only able to answer seventeen until thirty questions. In the pretest, the students make many mistakes in answering the question of adjectives vocabulary. They make a mistakes by answering the question about adjectives of the taste, such as 1 . "I cannot bite the meat. Its so. ?" and the choice is 4 . A. Crispy, B. Chewy, C. Crumbly and D. Fizzy. Many students make a mistake they answer C and D, the correct one is B. Chewy. 2. "We fried......Sardines with sweet peppers, onions and tomatoes, and served it with whole wheat bread". The choise is A. Briny, B. Acid, C. Sour, D. Creamy. The correct answer is A. Briny, but they answer C and D They make a mistakes because of they unfamiliar with the vocabulary.

During the treatments, it was found that the students are interesting with the lesson, they enthustiastic when teaching learning process. As well as they are made mistakes in answering questions in the pretest of vocabulary. However, the students improve their vocabulary mastery during the treatments.

As the result, the scores of both experimental and control group in the posttest are improved. Table 4.1 shows that the total score of experimental group in posttest is 2807.5. It improves 457.8 points from the pretest score. In the posttest each student of experimental group gets 16 to 35 points higher than in pretest. Meanwhile, the total score of control group in posttest is 2550. It improves 374 points from the pretest score. In the posttest each student of control group gets 3 to 13 points higher than in pretest. Those results show that the experimental group scores increase significantly higher than control group. It is almost 500 points higher than control group score in the posttest. So, we can conclude that students who are given treatments by using crossword puzzle have higher score than those given treatments by traditional teaching.

After learning vocabulary using crossword puzzle in three meetings, students improve their vocabulary mastery. They can minimize or even omit the mistakes in a question. Based on the result of experimental group in posttest, the students improve their vocabulary, they can answer adjectives of taste such as, "do not eat a food, you are coughing". A. Creamy, B. Mushy, C.Bitter and D. Greasy. Many students made a right answer. The correct one is D. Greasy. "Rosa had a bowel of.........Cereal for breakfast" A. Bitter, B.Spicy, C.Minty, D. Crunchy. The correct answer is D. Crunchy. All of students made a right answer. 
The result analysis of independent sample t-test shows that the experimental and control group mean scores in pretest are not significantly different. Table 4.3 shows that $\mathrm{t}$ - count is lower than $\mathrm{t}$ table $(1.373<1.9966)$. It also shows that the sig. 2 -tailed value is higher than sig. level $(.174>0.05)$. Thus it can be concluded that the two groups have the same level of vocabulay mastery before the treatments.

Then, the t-test analysis of the mean score of experimental and control group in the posttest shows that the mean score of experimental group is higher than the mean score of control group. Table 4.5 shows that $\mathrm{t}$-count is higher than $\mathrm{t}$-table $(4.454>1.9966)$. It also shows that the sig. 2 -tailed value is lower than sig. level $(0.000<0.05)$. Therefore, the null, hypothesis $(\mathrm{Ho})$ is rejected and the alternative hypothesis (Ha) is accepted. It means that there is improvement on students' vocabulary mastery by using crossword puzzle as technique than those who are taught by using traditional teaching.

\section{CONCLUSION}

After analyzing the results of the research, there are several facts that should be summarized. First, the students' control and experimental score are quite low on the pretest. The total score of experimental group is 2349.7 while control group is 2176 in the pretest, most students make many mistakes in answering the task. Second, during the treatments of the students increase their vocabulary mastery. As a result, on posttest their score was improved. However, the student experiment group score increased significantly higher than the control group. The total score of the experimental group on the posttest is 2807.5 . This is about 300 points higher than the control group.

Third, the result of independent sample t-test shows that the students' mean score of experimental and control group in pretest are not significantly different. It shows that $\mathrm{t}$-count is lower than $\mathrm{t}$ table $(1.373<1.9966)$, It also shows that the sig. 2-tailed value is higher than sig. level $(174>0.05)$. So, it means that the two groups have the same level of vocabulary mastery before the treatments.

Fourth, the result of independent sample t-test in the posttest shows that the students' mean score of experimental and control group in the posttest are significantly different. It shows that $t$-count is higher than t-table $(4.454<1.9966)$. It also shows that the sig. 2 -tailed value is lower than sig. level $(0.000>0.05)$. Therefore, the null hypothesis $(\mathrm{Ho})$ is rejected and the alternative hypothesis $(\mathrm{Ha})$ is accepted.

From the above facts, it can be concluded that the crossword puzzle is a good medium to improve students' vocabulary mastery. This is evidenced by the results of the mean score analysis of students on the posttest which shows the rejection of the null hypothesis (Ho) and acceptance of alternative hypothesis (Ha). This means that there is an effective impact of using crossword puzzles to students' vocabulary. Therefore, crossword puzzle is effective to improve students' vocabulary mastery in second grade students of SMA Muhammadiyah 2 Bandar Lampung.

\section{REFERENCES}

Alqahtani, M (2015). The Importance of Vocabulary in Language Learning and How to be Thaught. International Journal of Teaching and Education.

Arikunto, S. (2010). Prosedur Penelitian Suatu Pendidikan. Jakarta Rineka Cipta.

Brown, H. D.( 2001). Teaching by Principles: An Interactive Approach to Language Pedagogy, Second Edition. New York. A Pearson Educational Company.

Cresswell, J.C. (2012). Education Research, Planning, Conducting, and Evaluating Quantitative and Qualitative Research. Retrieved from https://deceng3.wordpress.com/daftarpustaka/ 
Dhand, H. (2008). Techniques of Teaching. New Delhi. APH Publishing Corporation. Elfrieda. H and Michael, K (2005). Teaching and Learning Vocabulary. London.

Graves, Michael F. (2009). The Vocabulary Book: Learning and Instruction. New York: Teacher Collage Press and IRA.

$\mathrm{Gu}$, Y. (2005). Vocabulary Learning Strategies in the Chinese ELF Context. Singapore: Marshall Cavendish Academic.

Harmer, J (2001). The Practice of English Language Teaching. Goldstone Books Liandybie: United kingdom.

Harmer, J. (2007). The Practice of English Language Teaching. London. Pearson Longman

Hatch, E., \& Brown,C. (1995). Vocabulary, Semantics, and Language Education. New York: Cambridge University Press

Huckin, Thomas, Ed (1995). Second Language Reading and Vocabulary Learning. Retrieved from https:eric.ed.gov/?id=ED394311

Laufer, B. and Nation, P (1999). A vocabulary-Size Test of Controlled Productive Ability. English Department, University of Haifia.

Meara, P. (1980) Vocabulary Acquisition: A Neglected Aspect of Language Learning. Cambridge University Press.

Michael, G. (2012) Teaching Vocabulary to English Language Learners. Columbia University New yok and London.

Morley, G. David, (2000) Syntax in Functional Grammar: An Introduction to Lexicogrammar in Systematic Linguistics. London.

Moursund, Dave. (2007) Introduction to Using Games in Education: A guide for teachers andparents. Retrieved from http://pages.uoregon.edu/moursund/Books/Games/Games.pdf

Oxford, R. (1990). Vocabulary Learning: A Critical Analysis of Technique. TESL Canada Journal. Volume 7, Issue 2.

Oxford, R. (2006), Teaching Young Language Learners, A. Pinter. Oxford University Press,192 pp.

Pinter, A. (2006) Teaching Young Language Learners. Oxford University Press, I92p.

Prasetyo, Y. D., Kurniawati, and Subari (2013). The Influence of Series Picture on the Students' writing Recount text Ability. The International Conference on Education and Language, Bandar Lampung University: 28-30 January 2013. Indonesia

Richards, J. and Willy A. Renandya.( 2002). Methodology in Language Teaching: An Anthology of Current Practice. New York . Cambridge University Press.

Schmitt. N (2008) Vocabulary Language Teaching. Cambridge University.

Thonburry, S (2002: 13). How to Teach Vocabulary. London. Pearson Education Limited.

Webb, S. (2009) The Effect of Pre-learning Vocabulary on Reading Comprehension and Writing. Victoria University of Wellington.

Webster, M. (1992) Vocabulary Builder. Retrieved from https://www.amazon.co.uk/MerriamWebster-Vocabulary-Builder-Merriam-Webster/dp/0877798559

Zein, M. (2012) Language Teacher Education for School English Teacher in Indonesia. Retrieved from

https://www.researchgate.net/profile/SubhanZein/publication/30090051languageteachereducationf orschoolenglishteacherinindonesiapolicyrecommendations.pdf 